\title{
A Review on Management of Weeds in Maize (Zea mays L.)
}

\author{
Anwesh Rai ${ }^{1 *}$, Debasis Mahata ${ }^{1}$, Everest Lepcha ${ }^{1}$, Kousik Nandi ${ }^{1}$ and \\ Pijush Kanti Mukherjee ${ }^{2}$
}

\author{
${ }^{1}$ Department of Agronomy, Uttar Banga Krishi Viswavidyalaya, Pundibari, Cooch Behar, \\ West Bengal-736165, India \\ ${ }^{2}$ Farm Section, Indian Veterinary Research Institute (IVRI), Izatnagar, Bareilly, \\ Uttar Pradesh-243122, India \\ *Corresponding author
}

\section{A B S T R A C T}

\section{Keywords \\ Weed flora, Weed management practices, Weed density, Weed dry weight, Weed control efficiency \\ Article Info \\ Accepted: \\ 17 July 2018 Available Online: \\ 10 August 2018}

Weeds constituent one of the major economic important problem for maize growers and it can reduce yield up to 86 per cent. The magnitude of losses largely depends upon the composition of weed flora, period of crop-weed competition and its intensity. The highest weed control efficiency with lowest weed density and weed dry weight was noted in pre-emergence application of atrazine @ $1.0 \mathrm{~kg}$ a.i. ha ${ }^{-1}$ followed by $(f b)$ one hand weeding (HW) at 30 DAS.

\section{Introduction}

Maize (Zea mays L.) is the third most important cereal crop of India. It is grown for fodder as well as for grain purpose. Among various other factors, weed is one the most important yield limiting factor. Their effects could be quite variable, but the most common is competition for available resources which leads to the drastic reduction in yield. Weed management strategies viz. mechanical, chemical and biological and integration of these three methods i.e. integrated weed management practices have been developed to limit the deleterious effects of weeds on crop plants.

\section{Weed flora associated with maize crop}

Dominant weed species present in the experimental site were Cynodon dactylon L., Cyperus rotundus L., Amaranthus viridis L., Anagalis arvensis L., Argemone maxicana L., Chenopodium album L., Melilotus indica L., Oxalis corniculata L., Convolvulus arvensis L., Rumex retroflex L. and Parthenium hysterophorus L. (Kumar et al., 2017). Among the different weed species that were observed in the field experiment, the major 
weed species were: Cynodon dactylon, Cyperus rotundus, Parthenium hysterophorus L. and Chenopodium album L. (Abdullah et al., 2016). The important weeds noticed during winter (rabi) season were Phalaris minor, Poa annua among grass and Medicago denticulata, Anagallis arvensis, Circium arvense, and Chenopodium album among broad-leaf weed (Stanzen et al., 2016).

The major weed flora during kharif season in experimental field was composed of Xanthium strumarium, Celosia argentea, Tridax procumbens, Phyllanthus niruri, Euphorbia geniculata, Euphorbia hirta, Alternanathera triandra, Parthenium hysterophorus, Digera arvensis, Cynodon dactylon, Cyperus rotundus, Amaranthis viridis, Dinebra arabica, Panicum spp, Commelina benghalensis (Kakade et al., 2016).

Mukherjee and Rai (2015) observed that major weed flora were Polygonum persicaria, $P$. pensylvanicum, $P$. orientale, Oldenlandia diffusa, Oldenlandia aquatic, Oxalis corniculata, Stellaria media, Stellaria aquatic, Physalis minima, Solanum nigrum, Hydrocotyl ranunculoides, Ageratum conyzoides (appeared at latter part of crop growth), the sedge like Cyperus rotundus and the grasses like Cynodon dactylon, Digitaria ciliaris, Setaria glauca, Echinochloa sp. Among these weeds Polygonum sp., Cynodon dactylon, Digitaria ciliaris, Setaria glauca were highly aggressive in maize. However, Singh et al., (2015), reported that the dominant weeds in the maize field were: Medicago denticulata, Avena ludoviciana, Phalaris minor and Chenopodium album.

Swetha, (2015) reported that the weed spectrum of the experimental field consisted of all three groups of weeds viz., grasses, sedges and broad leaved weeds. Cynodon dactylon L., Digitaria sanguinalis L.,
Dactyloctenium aegyptium L., Echinocloa spp and Rottboelli aexaltata L among grasses, Parthenium hysterophorus L., Commelina benghalensis L., Amaranthus viridis L., Euphorbia geniculata L., Digera arvensis L and Trianthema portulacastrum $\mathrm{L}$ among the broadleaved weeds and the sedge Cyperus rotundus $\mathrm{L}$.

Kannan and Chinnagounder (2014) reported that weed flora of the experimental field in maize predominantly consist of 12 species of broad leaved weeds, 5 species of grasses and a sedge weed. The dominant among broadleaved weeds were Trianthema portulacastrum, Datura stramonium, Cleome gynandra, Digera arvensis, Physallis minima, and Corchorus olitorius. The dominant grass weeds were Setaria verticillata and Cynodon dactylon, $C$. rotundus was the only sedge present in the experimental field. With respect to individual weed species during both the years, density of $T$. portulacastrum recorded about $162.80 \%$.

Madhavi et al., (2014) identified the major weeds in maize field were Cyperus rotundus L. among the sedges, Digitaria spp, Dactyloctenium aegyptium L., Dinebra arabica L., Cynodon dactylonL., and Eleusine indica L. among grasses; Parthenium hysterophorus L., Melilotus alba L., Trianthema portulacastrum L., Euphorbia geniculate L., Commelina spp, Tridax procumbens L. and Amaranthus viridis L. among broad leaf weeds.

Madhavi et al.,(2013) reported that predominant weed flora in the experimental field comprised of Cyperus rotundus, Cynodon dactylon, Digitaria sanguinalis, Dactylocteniuma egyptium, Rottoboellia exaltata, Parthenium hysterophorus, Celosia argentia, Euphorbea hirta, Digera arvensis and Trianthema portulacastrum.

Ravisankar et al., (2013) observed that the 
broad leaved weeds were dominating over grasses and sedge in the experimental field. Among the individual weed species, Trianthema portulacastrum, Cleome gynandra, Digera arvensis, Datura stramonium, Cynodon dactylon, Dactyloctenium aegyptium, Comme- lina bengalinsis and Cyperus rotundus were predominant in maize field. Among broad leaved weeds, Trianthema portulacastrum was the dominant one during both the seasons. Similar studies reported that maize crop infested with major broad leaved weeds were Trianthema pórtulacastrum, Digera arvensis, Phyllanthus niniri, Amaranthus viridis. Among the grassy weeds Cynodon dactylon and Dactyloctenium aegyptium had dominated. Cyperus rotundus was the major sedge weed (Ramesh and Nadanassababady, 2005).

The predominant weeds under monocot were Echinochloa colona (15.4\%), Digiteria sanguinalis (13.1\%), Cyperus rotundus (16.2\%) and Commelina communis (14.0\%). Phyllanthus niruri (14.4\%) and Eclipta alba (13.6\%) were prominent among dicot weeds. Many other minor weeds in small intensity $(13.3 \%)$ were also present in maize ecosystem at 60 DAS stage (Sanodiya et al., 2013).

The predominant weed flora of the experimental field was Rough leaf cocklebur (Xanthium brasilicum Vell), Jimson weed (Datura stramonium Mill), Asthma weed (Euphorbia hitra L.), Purslane (Portulaca oleracea L.), Plodder Hibiscus (Hibiscus trionum L.), Tar vine (Boerhavia erecta L), White pigweed (Amaranthus graecizans L.), Pigweed (Amaranthus vridis L), Grip weed (Phyllanthus niruri L), Black night shade (Solanum nigrum L.), Common cal traps (Tribuls terrestris L.), Water grass (Echinochloa colona (L.) Link), Tropical crab grass (Digitaria ciliaris Retz), Love grass (Eragrostis magastachya Koel) and (Dinebra retroflexa Vahi) (Babiker et al., 2013).

Singh et al., (2012) observed uniform infestation of the grassy weeds Echinochloa colona L., Digitaria sanguinalis L. and Bracharia ramose L., while the broad leaf weed included Phyllanthus niruri L., Cleome viscose $\mathrm{L}$ and Trianthema monogyna L., Cyperus rotundus L., was the only sedge in sandy loam soil of Uttarakhand.

The predominant weed flora were Echinochloa crusgalli L. and Cynodon dactylon L. among monocots; Cyperus rotundus L. among sedges; and Amaranthus viridis L., Digera arvensis L., Portulaca oleracea L., Alternenthara sessili L. and Trianthema spp. among dicots. (Arvadiya et al., 2012).

The important grassy weeds observed were Cynadon dactylon, Dinebra retroflexa, Echinocloa colanum, Elusine indica. Cyperus rotundus was alone in sedge category. Among the broad leaved weeds Parthenium hysterophorus, Commelina bengalensis, Portulaca oleracea, Cynotis cuculata, Phylantus niruri and Amaranthus viridis were the dominant weeds (Haj et al., 2012).

Kumar et al., (2012) observed that weed flora was composed of Commelina benghalensis (25.6 and $12.3 \%$ at 60 DAS and at harvest, respectively), Ageratum conyzoides (45.1 and $56.1 \%)$, Echinochloa colona (L.) Link (17.6\% and $8.7 \%)$, Panicum dichotomiflorum (8.4 and $7.7 \%$ ), Cyperus iria (2.8 and 7.2\%), Digitaria sanguinalis (0.0 and $8.2 \%)$ and Polygonum alatum (0.5 and 8.0\%).

Sunitha et al., (2010) reported that during both the years of study, 23 weed species including six grasses, two sedges and 15 broad-leaved weeds were identified in the experimental field. Among these, Panicum repens (21.4\%), Digitaria sanguinalis 
(18.5\%), Celosia argenta (16.4\%), Acanthospermum hispidum (15.5\%) and Cleome viscosa $(14.0 \%)$ were found to be the dominant weeds.

\section{Yield reduction in maize due to weeds}

A number of weed species compete with corn plant and have been observed to reduce yield as much as $65 \%$ with delay in weed control. Weeding in maize after the critical period of weed removal can result in up to $83 \%$ losses in grain yield (Ehsas et al., 2016).

Maize weeds comprise diverse plant species from grasses to broadleaf weeds and sedges and cause substantial yield losses (18-85\%) (Jagadish et al., 2016).

Yield loss occurs up to $33 \%$ to complete crop failure due to weed competition in maize (Kakade et al., 2016).

In India, the presence of weeds, in general reduces the maize yield by 27-60\%, depending upon the growth and persistence of weed population in maize crop (Kumar et al., 2015 and Jat et al., 2012). However, Yakadri et al., (2015) opined that wider spacing and initial slow growth of maize during the first 3 4 weeks provides enough opportunity for weeds to invade and offer severe competition, resulting in 30-93\% yield losses.

Mahadevi et al., (2014) reported that maize being a widely spaced crop gets infested with a variety of weeds and subjected to heavy weed infestation, which often inflicts huge losses ranging from 28 to $100 \%$.

Kannan and Chinnagounder (2013) opined that weeds constituent one of the major economic important problem for maize growers because they can reduce yield up to 86 per cent.

Ramachandran et al., (2012) opined that weed causes drastic reduction in growth, development and yield of the maize and accounts for $40 \%$ yield loss and even $>70 \%$ yield loss under uncontrolled weed growth condition in maize.

Sunitha and Kalyani (2012) reported reduction in grain yield of maize due to weed infestation ranged from 40 to 60 per cent depending upon the intensity and types of weed flora. However, Kumar et al., (2015) opined that reduction in maize grain yield by weeds is in tune of $50.3 \%$.

The extent of reduction in grain yield of maize has been reported to be in range of 33 to 50 percent depending on the weed species in standing crop (Hawaldar and Agasimani, 2012).

\section{Weed management practices}

\section{Cultural control}

The maximum grain yield of $\left(8.92 \mathrm{tha}^{-1}\right)$ and minimum weed density and dry weight of all major weed species were recorded in 2 hand weeding (HW) at 15 and 30 days after sowing (DAS) (Kumar et al., 2017).

At harvest, the significantly lower monocot and sedges were noted under weed control through sugarcane trash mulch @ $5 \mathrm{t} \mathrm{ha}^{-1}$ (Ehsas et al., 2016).

Stanzen et al., (2016) observed that 2 HW recorded significantly higher number of grains $\mathrm{cob}^{-1}, 1,000$-grain weight and grain yield which was statistically at par with atrazine $1 \mathrm{~kg} \mathrm{ha}^{-1}$.

Samanth et al., (2015) reported maximum grain yield in farmer's practice (HW at 20 and 40 DAS) and was $f b$ atrazine @ $1.0 \mathrm{~kg}$ a.i ha ${ }^{-1}$ as $\mathrm{PE} f b \mathrm{HW}$ at $30 \mathrm{DAS}$.

Pathak et al., (2015) reported that hoeing at 
20 DAS $f b$ atrazine $0.50 \mathrm{~kg} \mathrm{ha}^{-1}$ being at par with $2 \mathrm{HW}$ (20 and 40 DAS), registered significantly higher weed control efficiency (WCE) at all growth stages of maize.

Swetha (2015) reported that HW at 20 and 40 DAS recorded higher grain yield $(6580 \mathrm{~kg}$ $\left.\mathrm{ha}^{-1}\right)$ which was on par with topramezone + atrazine @ 25.2 + 250 g a.i ha ${ }^{-1}$ as PoE (6436 $\mathrm{kg} \mathrm{ha}^{-1}$ ).

Stover yield and harvest index was also higher in HW at 20 and 40 DAS.

Kumar et al., (2015) reported that brown manuring helps in suppressing the weeds up to $50 \%$ of total weed population on the account of the shade effect of killed green manure till 45 DAS up to which the critical period of crop weed competition continues in maize.

Madhavi et al., (2014) found that HW reported significantly higher grain yield on par with tank mix of topramezone + atrazine along with adjuvant MSO (@ 25.2+250 g a.i $\mathrm{ha}^{-1}$ and $21+250 \mathrm{~g}$ a.i ha $^{-1}$ ) and topramezone (a) $25.2+250 \mathrm{~g}$ a.i ha ${ }^{-1}$ without adjuvant.

Deshmukh et al., (2014) reported that the atrazine $1.0 \mathrm{~kg} \mathrm{ha}^{-1}$ as PE $f b$ mechanical $/ \mathrm{HW}$ at 30 DAS proves better in controlling weed, dry matter accumulation, WCE, grain yield and net monetary returns.

Kumar et al., (2013) reported that highest grain yield was recorded in conventionaltillage maize where HW at 15 and 30 DAS on par with zero-tillage maize where glyphosate was applied as pre-plant incorporation followed by atrazine + halosulfuron @ $1.0 \mathrm{~kg}$ a.i ha ${ }^{-1}+90 \mathrm{~g}$ a.i ha ${ }^{-1}$ as post-emergence (PoE).

Sanodiya et al., (2013) found that the highest grain yield and stover yields was noted in HW at 20 and 40 DAS $f b$ atrazine $1.0 \mathrm{~kg} \mathrm{ha}^{-1}+$

\section{HW at 30 DAS.}

Saini et al., (2013) from Palampur revealed that soybean intercropping + one mechanical weeding (20 DAS) recorded significantly lowest weed dry weight, higher yield attributes and maize equivalent yield which was at par with 2 mechanical weedings (20 and 40 DAS) + mash intercropping in maize among all other treatments.

Madhavi et al., (2013) reported that highest grain yield recorded in HW treatment $(7450$ $\mathrm{kg} \mathrm{ha}^{-1}$ ) which was significantly superior to singular applications of pendimethalin (5350 $\left.\mathrm{kg} \mathrm{ha}{ }^{-1}\right)$ or oxyfluorfen $\left(6020 \mathrm{~kg} \mathrm{ha}^{-1}\right)$ or atrazine $\left(6570 \mathrm{~kg} \mathrm{ha}^{-1}\right)$.

Malviya et al., (2012) noticed that highest grain yield was recorded in alachlor @ $2 \mathrm{~kg}$ a.i ha ${ }^{-1} f b$ one HW and was at par with weed free treatment.

Ahmed and Susheela (2012) opined that the farmer`s practice of eliminating weeds through intercultivation (IC) at 20 DAS $f b$ HW 30 DAS reduced the weed density and weed dry matter production significantly and thereby increased the WCE $(89.2 \%)$.

Sultana et al., (2012) found that two spading as intercultural operation along with $\mathrm{HW}$ at 10 and 20 days after emergence (DAE) + earthing-up at $30 \mathrm{DAE}$ recorded the highest grain yield $\left(7.74 \mathrm{t} \mathrm{ha}^{-1}\right)$ along with highest WCE (96.39\%) and lowest weed dry weight.

Sarma et al., (2010) found two HW at 25 and 45 DAS to be best in producing higher yield of maize along with minimum weed density $(4.0 \%)$ and weed dry weight $(3.3 \%)$.

Prasad et al., (2008) reported that manual weeding at 15 and 30 DAS recorded the highest WCE $(70.90 \%)$ with grain yield of $32.30 \mathrm{q} \mathrm{ha}^{-1}$. 
Gopinath and Kundu (2008) reported that PE application of atrazine at $1.25 \mathrm{~kg} \mathrm{ha}^{-1}$ coupled with one HW resulted in significantly lower weed population and weed dry weight compared to the other treatments. Twice HW at 20 and 40 DAS and PE application of atrazine @ $0.50 \mathrm{~kg}$ a.i ha ${ }^{-1}$ in combination with pendimethalin@0.25 kg a.i.ha ${ }^{-1}$ were found to be superior and recorded higher grain yield (3658 and $3652 \mathrm{~kg} \mathrm{ha}{ }^{-1}$, respectively) (Patel et al., 2006).

Hoeing at 15 DAS controlled the growth of all weed species and their population at 30 DAS was less than half (23-32 weeds $\left.\mathrm{m}^{-2}\right)$ compared with no inter-culture (67-70 weeds $\mathrm{m}^{-2}$ ). Earthing up at 30 DAS resulted in the virtual elimination of weeds throughout the crop growth period (Sharma et al., 2000).

\section{Chemical control}

Sahoo et al., (2017) found that highest grain yield of $81.38 \mathrm{q} \mathrm{ha}^{-1}$ was obtained with the application of atrazine @ $1 \mathrm{~kg} \mathrm{ha}^{-1}$ in maize.

Ehsas et al., (2016) reported that among herbicide treatment, PE application of atrazine@0.75 kg ha ${ }^{-1}+$ pendimethalin @ $0.75 \mathrm{~kg} \mathrm{ha}^{-1}$ recorded significantly higher grain yield of $6267 \mathrm{~kg} \mathrm{ha}^{-1} \mathrm{fb} \mathrm{PE}$ application of alachlor@1.5 kg ha ${ }^{-1}+$ atrazine@ $0.5 \mathrm{~kg}$ $\mathrm{ha}^{-1}\left(5918 \mathrm{~kg} \mathrm{ha}^{-1}\right)$.

These findings corroborate the results of Patel et al., (2006), Sanodiya et al., (2013) and Mathukia et al., (2014) in maize.

Sraw et al., (2016) observed the highest average grain yield of maize $\left(4.9 \mathrm{t} \mathrm{ha}^{-1}\right)$ was recorded in maize intercropped with cowpea (used as mulch) $f b$ maize intercropped with cowpea (used as fodder) at 30 DAS which was 27.9 and $22.2 \%$ respectively, higher as compared to control.
Kakade et al., (2016) reported that sequential application of $\mathrm{PE}$ and $\mathrm{PoE}$ herbicides $i: e$, atrazine $0.50 \mathrm{~kg} \mathrm{ha}^{-1} \mathrm{fb} 2,4-\mathrm{D}$ sodium salt 0.5 $\mathrm{Kg} \mathrm{PoE}$ at 30 DAS proves better in controlling weeds and found economical compare to conventional weed management practice in maize.

Kumar et al., (2012) opined that atrazine 1.0 $\mathrm{kg} \mathrm{ha}^{-1}+$ pendimethalin $0.5 \mathrm{~kg} \mathrm{ha}^{-1}$ (PE) $\mathrm{fb}$ 2,4-D $0.75 \mathrm{~kg} \mathrm{ha}^{-1}$ (PoE), $f b$ atrazine $1.5 \mathrm{~kg}$ $\mathrm{ha}^{-1}$ (PE) $\mathrm{fb}$ atrazine $0.75 \mathrm{~kg} \mathrm{ha}^{-1}$ (PoE) could be the better alternatives to $\mathrm{HW}$ in managing different flushes of weeds in maize.

Application of atrazine $1.5 \mathrm{~kg} \mathrm{ha}^{-1}$ recorded grain yield of $44.48 \mathrm{q} \mathrm{ha}^{-1}$ which was on par with atrazine $0.75 \mathrm{~kg} \mathrm{ha}^{-1}$ and pendimethalin $1.0 \mathrm{~kg} \mathrm{ha}^{-1}$ and 9.94 per cent higher yield than pendimethalin $1.5 \mathrm{~kg} \mathrm{ha}^{-1}$ because of the herbicides prevented the germination of weed and reduced the growth of weed (Samant et al., 2015).

Kannan and Chinnagounder (2014) reported that among the weed control treatments, PoE application of glyphosate at $1800 \mathrm{~g}$ a.i. $\mathrm{ha}^{-1}$ in transgenic corn hybrid recorded higher grain yield of $12.21 \mathrm{t} \mathrm{ha}^{-1}$.

Hatti et al., (2014) observed that significantly higher grain yield was recorded in oxyflurofen@200 g a.i ha ${ }^{-1}$ + 2, 4-D Na@ $500 \mathrm{~g}$ a.i ha ${ }^{-1}$ as PoE which was on par with $\mathrm{HW}$ at 20 and $40 \mathrm{DAS}$.

Chhetri et al., (2014) found that atrazine at the dose of $1.1 \mathrm{~kg} \mathrm{ha}^{-1}$ can be applied in maize safely as PoE application treatment for effective controlling weeds. Higher grain yield $\left(5,173 \mathrm{~kg} \mathrm{ha}^{-1}\right)$ was achieved in atrazine $1.0 \mathrm{~kg} \mathrm{ha}^{-1} \mathrm{fb}$ atrazine $1.0 \mathrm{~kg} \mathrm{ha}^{-1}$ treated plot (Ahmed and Susheela, 2012).

Nadiger et al., (2013) observed higher grain yield $\left(10,436 \mathrm{~kg} \mathrm{ha}^{-1}\right)$ with application of atrazine $1.25 \mathrm{~kg} \mathrm{ha}^{-1}$ due to effective control 
of weeds and minimum dry weight $[1.80$ (2.73) $\mathrm{g} \mathrm{m}^{-2}$ ] of weeds.

Kannan and Chinnagounder (2013) reported that PoE application of potassium salt of glyphosate at $1800 \mathrm{~g} \mathrm{ha}^{-1}$ in transgenic and conventional maize hybrid of $30 \mathrm{~V} 92$ enhanced the complete control of broad spectrum weeds and hence significantly lowered weed density, weed dry weight and higher WCE ranging from 96- 99\%.

Singh, et al., (2012) reported that PoE application of tembotrione $120 \mathrm{~g} \mathrm{ha}^{-1}$ along with surfactant $\left(1000 \mathrm{ml} \mathrm{ha}^{-1}\right)$ was found most effective to control the grassy as well as nongrassy weeds as compared to other herbicidal treatments either applied as pre- or postemergence with maximum WCE (90\%).

Reddy et al., (2012) reported the highest grain yield $170 \%$ higher than that of unweeded control along with lowest density (no. $\mathrm{m}^{-2}$ ) and dry weight $\left(\mathrm{g} \mathrm{m}^{-2}\right)$ of grasses, and broadleaved weeds at 30 DAS with tank mix application of atrazine + glyphosate $(0.75+$ $\left.0.8 \mathrm{~kg} \mathrm{ha}^{-1}\right)$.

Glyphosate $\left(1.6 \mathrm{~kg} \mathrm{ha}^{-1}\right)$ was found superior to atrazine $\left(1.5 \mathrm{~kg} \mathrm{ha}^{-1}\right)$ and paraquat $(1.5 \mathrm{~kg}$ $\mathrm{ha}^{-1}$ ) for density, dry weight of weeds and WCE.

Singh et al., (2012) observed that tembotrione @ $120 \mathrm{~g}$ a.i ha ${ }^{-1}$ as PoE along with surfactant recorded significantly highest grain yield and was on par with reduced dose of $110 \mathrm{~g}$ a.i ha ${ }^{-1}$ + surfactant and HW at 20 and 40 DAS.

Ramachandran et al., (2012) observed the highest grain $\left(7.23 \mathrm{t} \mathrm{ha}^{-1}\right)$ and stover yield $\left(11.56 \mathrm{t} \mathrm{ha}^{-1}\right)$ with PE alachlor $1.0 \mathrm{~kg} \mathrm{ha}^{-1}+$ brown-manuring. It was closely followed by $\mathrm{PE}$ alachlor $1.0 \mathrm{~kg} \mathrm{ha}^{-1}+$ daincha as intercrop with in-situ incorporation on 35 DAS (6.38 and $10.20 \mathrm{tha}^{-1}$ ).

Significantly higher seed yield (5302 $\mathrm{kg} \mathrm{ha}^{-1}$ ) was obtained in atrazine $1.25 \mathrm{~kg} \mathrm{ha}^{-1} \mathrm{fb}$ glyphosate $2.5 \mathrm{~kg} \mathrm{ha}^{-1}$ when compared to weedy check (Haji et al., 2012).

Kumar et al., (2012) reported that pendimethalin $1.50 \mathrm{~kg} \mathrm{ha}{ }^{-1}$, atrazine $f b$ atrazine $0.75 \mathrm{~kg} \mathrm{ha}^{-1}$, atrazine $0.75 / 1.0+$ pendimethalin $0.75 / 0.50 \quad f b$ metsulfuron methyl $4 \mathrm{~g}$ ha $^{-1}$ effectively controlled Echinochloa colona. Atrazine $f b$ atrazine brought about significant reduction in the count of Panicum dichotomiflorum up to 60 DAS. Pendimethalin $f b$ atrazine, atrazine 1.0 + pendimethalin $0.50 \mathrm{fb}$ 2, 4-D $0.75 \mathrm{~kg} \mathrm{ha}^{-1}$ and HW twice effectively reduced the population of Commelina up to 60 DAS. Pendimethalin/atrazine $f b$ atrazine and atrazine + pendimethalin $f b \quad 2,4-\mathrm{D} /$ metsulfuron-methyl controlled Ageratum conyzoides up to 60 DAS.

Rani, et al., (2011) reported that application of sulfosulfuron $15 \mathrm{~g} \mathrm{ha}^{-1}+$ imazethapyr $25 \mathrm{~g}$ $\mathrm{ha}^{-1}$ as PE with HW at 40 DAS was found to be effective and economic weed management practice for irrigated sweet corn. Sunitha $e t$ al., (2010) reported that PE application of atrazine@1 kg ha ${ }^{-1} f b \mathrm{HW}$ at $30 \mathrm{DAS}$ provided significant weed control during the critical crop-weed competition period in sweet corn upto 45 DAS. Nadeem et al., (2010) reported that metolachlor + atrazine @ $1110+740 \mathrm{~g}$ a.i ha ${ }^{-1}$ as PE recorded highest grain yield on par with manual hoeing + earthing-up.

\section{Integrated weed management}

Abdullah et al., (2016) found that the most effective treatment in controlling weed population and increasing the grain yield of maize were atrazine @ $1.00 \mathrm{~kg} \mathrm{ha}^{-1}+\mathrm{HW}, 2$ HW and paddy straw mulching, producing grain yield of (203.48 g, $188.34 \mathrm{~g}$ and 186.82 g) respectively, as compared to un-weeded plot $(68.30 \mathrm{~g})$.

Rasool and Khan (2016) found that PE 
application of atrazine @ $1.0 \mathrm{~kg}$ a.i. ha ${ }^{-1}+$ $\mathrm{HW}$ at 20 DAS recorded maximum grain yield $f b$ atrazine @ $1.0 \mathrm{~kg}$ a.i. ha ${ }^{-1} \mathrm{PE}+$ isoproturon@1.0 kg a.i. ha $\left.{ }^{-1} \mathrm{PoE}\right)$. Maize + dhaincha (1:1) and (1:2) as green manure and maize alone with $2 \mathrm{HW}$ during 1 st year where as maize + cowpea as seed crop (1:1) and maize alone with $2 \mathrm{HW}$ during $2^{\text {nd }}$ year produced significantly higher yield and lower weed dry weight (Kumar et. al., 2015).

Kumar et al., (2013) reported that in zero tillage maize pre-plant incorporation of glyphosate $f b$ atrazine + halosulfuron @ (1.0 $+90 \mathrm{~g}$ a.i ha ${ }^{-1}$ ) as PoE resulted in highest grain yield.

Malviya et al., (2012) reported higher grain yield of maize with $\mathrm{HW}$ at 20 and 40 DAS and pendimethalin@1.0 kg a.i ha ${ }^{-1}$ as PE $f b$ HW at 30 DAS and were at par with weed free treatment.

Sanodiya et al., (2013) stated that lowest weed biomass was recorded in weed free treatment (HW at 20 and 40 DAS) $f b$ application of atrazine @ $1.0 \mathrm{~kg}$ a.i ha ${ }^{-1}$ as PE $f b$ hand weeding at 30 DAS.

Verma et al., (2009) revealed that in maizegreen gram system, manual weeding at 20 DAS $f b$ earthing up at 30 DAS in maize recorded significantly higher plant height, culm girth and dry weight of plant. Deshmukh et al., (2009) reported significantly higher grain yield and fodder yield with atrazine @ $0.75 \mathrm{~kg}$ a.i ha ${ }^{-1}$ as PE $f b$ one HW at 45 DAS.

Influence of weed management practices on weed characteristics and weed control efficiency

\section{Weed density}

Abdullah et al., (2016) found that maximum reduction in density of the weeds $\left(\mathrm{m}^{-2}\right)$ was observed with the treatment Paddy straw mulching (61.00) and Black polythene mulching (61.0) $f b$ pre-emergence atrazine @ $1.0 \mathrm{kgha}^{-1}$ + one HW @ 45 DAS (75.0).

Application of atrazine + pendimethalin 0.50 $+0.50 \mathrm{~kg} \mathrm{ha}^{-1}$ as PE similar to HW at 20 and 40 DAS recorded reduced weed density of narrow-leaf, broad-leaf and sedges at 30 and 60 DAS. The extent of reduction was to the tune of $69.8,96.9$ and $85.1 \%$ at 30 days and $73.7,85.7$ and $88.2 \%$ at 60 DAS, respectively (Barla et al., 2016).

Stanzen et al., (2016) reported the minimum density of weeds and biomass was observed under $2 \mathrm{HW}$ which was at par with atrazine 1 $\mathrm{kg} \mathrm{ha}^{-1}$.

Shankar et al., (2015) found that lower density and dry weight of weeds $\mathrm{m}^{-2}$ was recorded with atrazine $(50 \%) @ 1.25 \mathrm{~kg} \mathrm{lit}^{-1}$ or pendimethalin $(50 \%) @ 2.5 \mathrm{lit} \mathrm{ha}^{-1}$ as compared to other chemical weed management treatments.

Samant et al., (2015) reported that farmers practice produced the minimum weed density $\left(20.16 \mathrm{~m}^{-2}\right)$. PE application of atrazine $50 \%$ WP @ $1.0 \mathrm{kgha}^{-1} f b$ one HW at 30 DAS produced lower weed density $\left(47.52 \mathrm{~m}^{-2}\right)$ which found superior over rest of herbicidal treatments in controlling weed density.

Singh et al., (2015.) reported that lowest weed density $\left(49.5 \mathrm{~m}^{-2}\right)$ was recorded with pendimethalin $(1000 \mathrm{~g})+1 \mathrm{HW}$ which was statistically similar to pendimethalin $(500 \mathrm{~g})+$ atrazine $(500 \mathrm{~g})$ and both were significantly superior to weedy check.

Kannan and Chinnagounder, (2014) reported that lower weed density was achieved under non transgenic maize hybrid $\mathrm{BIO} 9681$ and 30B11 with PE application of atrazine at 0.5 $\mathrm{kg} \mathrm{ha}^{-1} \mathrm{fb} \mathrm{HW}$ at $20 \mathrm{DAS}$.

Shingrup et al., (2014) reported that the 
application of atrazine $0.75 \mathrm{~kg} \mathrm{ha}^{-1} \mathrm{PE} f b$ 2,4D PoE significantly reduced the weed population in maize.

Madhavi et al., (2014) observed that tank mix application of PoE herbicide topramezone + atrazine@25.2+250 g a.i ha ${ }^{-1}$ recorded significantly lowest density of weeds compared to other treatments.

Lowest weed dry matter and highest WCE readings were recorded with HW (89.8\%) $f b$ atrazine $f b$ intercultivation $(87.5 \%)$, oxyfluorfen $f b$ intercultivation $(84.2 \%)$ and pendimethalin $f b$ intercultivation $(81.3 \%)$ (Madhavi et al., 2013).

Nadiger et al., (2013) reported that in maize HW $f b$ IC at 20 and 30 DAS recorded significantly lowest weed density on par with atrazine @ $1.25 \mathrm{~kg} \mathrm{a} . \mathrm{ha}^{-1}$ as PE $f b$ IC at 30 DAS.

Ramachandran et al., (2012) reported that PE alachlor $1.0 \mathrm{~kg} \mathrm{ha}^{-1}+$ brown manuring proved to be effective in registering the lowest weed density of grasses, sedges, broad-leaved weeds and total weeds.

Arvadiya et al., (2012) observed the marked reduction in weed density with PE application of atrazine $0.5 \mathrm{~kg} \mathrm{ha}^{-1}$ coupled with pendimethalin $0.25 \mathrm{~kg} \mathrm{ha}^{-1} \mathrm{fb}$ application of $\mathrm{PE}$ atrazine $1.0 \mathrm{~kg} \mathrm{ha}^{-1}$.

Sunitha and Kalyani (2012) found that the PE application of atrazine 0.5 to $1.0 \mathrm{~kg} \mathrm{ha}^{-1}$ in combination with $\mathrm{HW}$ at 30 DAS recorded lowest weed density.

Singh et al., (2012) reported that tembotrione @ $120 \mathrm{~g}$ a.i ha ${ }^{-1}$ as PoE along with surfactant effectively reduced the growth and density of grasses Echinochloa colona L. and Digitaria sanguinalis $\mathrm{L}$. sedge Cyperus rotundus $\mathrm{L}$.

Srividya et al., (2011) found that application of either atrazine $1.25 \mathrm{~kg} \mathrm{ha}^{-1}$ or pendimethalin $1.5 \mathrm{kgha}^{-1}$ in combination with paraquat $0.6 \mathrm{~kg} \mathrm{ha}^{-1}$ at 3 weeks after sowing (WAS) recorded lower weed density (16.67 $\left.\mathrm{m}^{-2}\right)$.

Dubey, (2008) found that application of pendimethalin $1.0 \mathrm{~kg} \mathrm{ha}^{-1}$ along with one HW at 30 DAS significantly reduced the density of weeds than weedy check.

Among weed control methods, atrazine $1.5 \mathrm{~kg}$ $\mathrm{ha}^{-1}$ being statistically at par with acetachlor $1.25 \mathrm{~kg} \mathrm{ha}^{-1}$ produced significantly lower density and dry matter of weeds and resulted in significant increase in all the yield attributes of maize crop and thereby its grain yield by 75.18 and $71.66 \%$, respectively, over unweeded check (Chopra and Angiras, 2008).

\section{Weed dry weight}

Barad et al., (2016) reported that the lowest dry weight of weed was observed under HW and IC at 15 and 30 DAS (208 kg ha ${ }^{-1}$ ), though it was found statistically at par with atrazine $0.5 \mathrm{~kg} \mathrm{ha}^{-1}$ as PE $f b \mathrm{HW}$ and IC at 30 DAS $\left(295 \mathrm{~kg} \mathrm{ha}^{-1}\right)$.

Ehsas et al.,(2016) reported that minimum dry weight of weeds $\left(60.96 \mathrm{~kg} \mathrm{ha}^{-1}\right)$ at harvest was recorded under treatment of $\mathrm{PE}$ application of atrazine @ $0.75 \mathrm{~kg} \mathrm{ha}^{-1}+$ pendimethalin @ $0.75 \quad \mathrm{~kg} \mathrm{ha}^{-1}$, which remained at par with $\mathrm{PE}$ application of alachlor@1.5 kg ha ${ }^{-1}+$ atrazine @ $0.5 \mathrm{~kg} \mathrm{ha}^{-1}$ $\left(68.53 \mathrm{~kg} \mathrm{ha}^{-1}\right)$. Samanth et al., (2015) reported that the minimum weed dry biomass $\left(27.05 \mathrm{~g} \mathrm{~m}^{-2}\right)$ was obtained in farmers practice of two HW at $20 \& 40$ DAS and among the herbicidal treatments PE application of atrazine 50\% WP@1.0 kg ha ${ }^{-1} f b$ one HW at 30 DAS recorded the minimum weed dry biomass $\left(40.57 \mathrm{~g} \mathrm{~m}^{-2}\right)$.

Singh et al., (2015), reported that application 
of pendimethalin $(1000 \mathrm{~g})+1 \mathrm{HW}$ recorded the lowest weed dry matter $\left(44.8 \mathrm{~g} \mathrm{~m}^{-2}\right)$ which was statistically similar to pendimethalin $(500 \mathrm{~g})+$ atrazine $(500 \mathrm{~g})$ and both were significantly superior to weedy check.

Kumari et al., (2014) concluded that acetachlor@2250 g a.i ha ${ }^{-1}$ as PE fb 2, 4-D $\mathrm{Na}$ salt @ $500 \mathrm{~g}$ a.i ha ${ }^{-1}$ as PoE recorded lowest weed dry matter on par with application of topramezone + atrazine $\left(25.2+250 \mathrm{~g} \mathrm{ha}^{-1}\right)$ and tembotrione + isoxadifen- ethyl @ $\left(105+52 \mathrm{~g} \mathrm{ha}^{-1}\right)+$ adjuvant as PoE.

Madhavi et al., (2014) noticed that lowest weed dry matter of weeds was recorded in tank mix application of topramezone + atrazine @ 25.2 + $250 \mathrm{~g}$ a.i ha ${ }^{-1}$ as PoE and was on par with application of topramezone + atrazine@ $21+250 \mathrm{~g} \mathrm{a} \cdot \mathrm{hha}^{-1}$.

Kannan and Chinnagounder (2014) found that considerable reduction in weed dry weight was recorded with the application of glyphosate at $1800 \mathrm{~g}$ a.e $\mathrm{ha}^{-1}$ in transgenic $30 \mathrm{~V} 92$ and POE controlled application of glyphosate at $1800 \mathrm{~g}$ a.e $\mathrm{ha}^{-1}$ in conventional maize hybrid of $30 \mathrm{~V} 92\left(1.58\right.$ and $\left.1.82 \mathrm{~g} \mathrm{~m}^{-2}\right)$ at 40 DAS.

Shingrup et al., (2014) observed the lowest weed dry matter accumulation due to application of atrazine $0.75 \mathrm{~kg} \mathrm{ha}^{-1} \mathrm{PE} f b$ 2,4D PoE. However, Nadiger et al., (2013) observed the minimum dry weight [1.80 (2.73) $\mathrm{g} \mathrm{m}^{-2}$ ] of weeds with application of atrazine $1.25 \mathrm{~kg} \mathrm{ha}^{-1}$.

In maize, significantly lowest weed dry weight was recorded with pre-plant incorporation of glyphosate $f b$ atrazine + halosulfuron@1.0 kg + $90 \mathrm{~g} \mathrm{a.i} \mathrm{ha}{ }^{-1}$ as PoE at 30 and 60 DAS, which was on par with preplant incorporation of glyphosate $f b$ topramezone + atrazine @ $40 \mathrm{ml}+500 \mathrm{~g} \mathrm{ha}^{-1}$ as PoE (Kumar et al., 2013).

Sanodiya et al., (2013) observed that tank mix application of atrazine + pendimethalin @ $0.75+0.75 \mathrm{~kg}$ a.i ha ${ }^{-1}$ recorded significantly lowest dry weight of Echinochloa colona L., Digitaria sanguinalis L., Cyperus rotundus L., Commelina benghalensis L. and Phyllanthus niruri L., at 60 DAS compared to application of herbicides alone. Singh et al., (2012) reported that tembotrione + surfactant @ $120 \mathrm{~g}$ a.i ha ${ }^{-1}$ as PoE recorded significantly lowest weed dry matter at 30 and 45 DAS.

Kumar et al., (2012) reported that pendimethalin $1.5 \mathrm{~kg} \mathrm{ha}^{-1} \mathrm{PE} f b$ atrazine 0.75 $\mathrm{kg} \mathrm{ha}^{-1}$ PoE, atrazine $1.5 \mathrm{~kg} \mathrm{ha}^{-1} \mathrm{PE} f b$ atrazine $0.75 \mathrm{~kg} \mathrm{ha}^{-1} \mathrm{PoE}$ were all effective in reducing total weed dry weight as compared to untreated check up to harvest.

Sunitha and Kalyani (2012) reported that the $\mathrm{PE}$ application of atrazine 0.5 to $1.0 \mathrm{~kg} \mathrm{ha}^{-1}$ in combination with $\mathrm{HW}$ at 30 DAS recorded lowest weed dry weight. Sequential application of atrazine $0.75 \mathrm{~kg} \mathrm{ha}^{-1} \mathrm{fb} 2,4-\mathrm{D}$ $1.0 \mathrm{~kg} \mathrm{ha}^{-1}$ recorded significantly lower dry weight of weeds which was on par with mechanical weeding (Hawaldar and Agasimani, 2012).

Haji et al., (2012) reported that lower total weed dry weight was noticed in atrazine 1.25 $\mathrm{kg} \mathrm{ha}^{-1} \mathrm{fb}$ glyphosate $2.5 \mathrm{~kg} \mathrm{ha}^{-1}$. Significant weed control was also reported by Sarma and Gautam (2010). At 45 DAS the lowest weed dry weight was recorded with tembotrione $120 \mathrm{~g} \mathrm{ha}^{-1}+$ surfactant $f b$ its lower dose (110 $\mathrm{g} \mathrm{ha}^{-1}+$ surfactant) (Singh et al., 2012).

Srividya et al., (2011) found that application of either atrazine $1.25 \mathrm{~kg} \mathrm{ha}$ or pendimethalin $1.5 \mathrm{~kg} \mathrm{ha}^{-1}$ in combination with paraquat $0.6 \mathrm{~kg} \mathrm{ha}^{-1}$ at 3 weeks after sowing (WAS) recorded lower weed dry matter comparable with that of two HW and IC with 
power weeder at $4 \mathrm{WAS}$.

Application of atrazine $0.5-1.25 \mathrm{~kg} \mathrm{ha}^{-1} \mathrm{had}$ significantly reduced the populations and dry weight of weeds (Anon., 2010). Chopra and Angiras (2008) opined that application atrazine $1.5 \mathrm{~kg} \mathrm{ha}^{-1}$ at 60 DAS was proved to be significantly superior in reducing the dry matter of weeds.

Rout and Satapathy (1996) and Sharma et al., (2000) also proved the superiority of atrazine to control weeds.

Significantly lower dry weight of weeds (28.8 $\mathrm{kg} \mathrm{ha}{ }^{-1}$ ) was achieved under treatment of atrazine + pendimethalin but was at par with weed free (Patel et al., 2006).

\section{Weed control efficiency}

Application of PE herbicides atrazine @ $1 \mathrm{~kg}$ ha $^{-1} f b$ glyphosate @ $2.5 \mathrm{~kg} \mathrm{ha}^{-1}$ was recorded with weed control efficiency (WCE) of 92.12 $\%$ next to weed free check (Sahoo et al., 2017).

Ehsas et al., (2016) observed that highest WCE was recorded under the treatment of PE application of atrazine @ $0.75 \mathrm{~kg} \mathrm{ha}^{-1}+$ pendimethalin@0.75 $\mathrm{kg} \mathrm{ha}^{-1}(88.97 \%) f b$ PE application of alachlor @ $1.5 \mathrm{~kg} \mathrm{ha}^{-1}+$ atrazine @ $0.5 \mathrm{~kg} \mathrm{ha}^{-1}(80.75 \%)$ and PE application of atrazine @ $0.75 \mathrm{~kg} \mathrm{ha}^{-1}+2,4-\mathrm{D}$ @ $0.5 \mathrm{~kg} \mathrm{ha}^{-1}(80.25 \%)$.

Sraw et al., (2016) reported that highest WCE (91.6\%) was observed in maize: cowpea (mulch 30 DAS) $f b$ maize: cowpea (fodder at 30 DAS). Atrazine @ $1.0 \mathrm{~kg} \mathrm{ha}^{-1} \mathrm{fb} \mathrm{HW}$ at 30 DAS gave least WCE due to higher weed dry weight (70.45 $\mathrm{g} \mathrm{m}^{-2}$ and $45.6 \mathrm{~g} \mathrm{~m}^{-2}$ respectively). Dimitrios et al., (2010) also found that maize intercropped with legumes considerably reduced the weed density compared with the mono-cropping maize.

Kakade et al., (2016) reported that the highest
WCE (80.09\%) and less weed index (13.50 $\%$ ) was achieved with atrazine $0.50 \mathrm{~kg} \mathrm{ha}^{-1} \mathrm{fb}$ 2, 4-D sodium salt $0.5 \mathrm{~kg} \mathrm{ha}^{-1}$ PoE $30 \mathrm{DAS}$.

Samant et al., (2015) found that the WCE varied from the maximum of $80.87 \%$ with farmers practice to the minimum of $54.12 \%$ with application of pendimethalin $1.5 \mathrm{~kg} \mathrm{ha}^{-1}$ $f b$ one HW at 30 DAS. Application with atrazine $1.0 \mathrm{~kg} \mathrm{ha}^{-1}$ as $\mathrm{PE} f b$ one $\mathrm{HW}$ at 30 DAS recorded higher WCE (71.31\%) than rest of herbicide treatments.

Mukherjee and Rai (2015) observed that highest WCE and lowest weed index values were registered with atrazine $\left(1.0 \mathrm{~kg} \mathrm{ha}^{-1}\right)$ as $\mathrm{PE}+$ atrazine $\left(1.1 \mathrm{~kg} \mathrm{ha}^{-1}\right)$ as PoE. Shankar et al., (2015) reported that highest WCE was found with application of atrazine (50\%) @ $1.25 \mathrm{~kg}$ or lit + pendimethalin (50\%)@ 2.5 lit ha $^{-1}$.

Madhavi et al., (2014) found that tank mix application of topramezone + atrazine @ 25.2 $+250 \mathrm{~g}$ a.i ha ${ }^{-1}$ as PoE along with adjuvant methylated seed oil recorded highest WCE of grasses, sedges and broad leaved weeds compared to application of herbicide without adjuvant.

Kamaiah et al., (2014) also found that tank mixture application of atrazine @ $0.625 \mathrm{~kg}$ $\mathrm{ha}^{-1}+$ pendimethalin@0 $0.5 \mathrm{~kg} \mathrm{ha}^{-1} f b$ 2,4-D (a) $0.5 \mathrm{~kg} \mathrm{ha}^{-1}$ recorded higher WCE.

Shingrup et al., (2014) reported that the highest WCE was achieved with the application of atrazine $0.75 \mathrm{~kg} \mathrm{ha}^{-1} \mathrm{PE} f b$ 2,4D PoE.

Madhavi et al., (2013) observed that lowest weed dry matter and highest WCE readings were recorded with $\mathrm{HW}(89.8 \%), f b$ atrazine $f b$ IC $(87.5 \%)$, oxyfluorfen $f b$ IC $(84.2 \%)$ and pendimethalin $f b$ IC $(81.3 \%)$.

Sanodiya et al., (2013) reported that WCE 
was maximum with $2 \mathrm{HW}$ closely $f b$ alachlor $2.5 \mathrm{~kg} \mathrm{ha}^{-1}+\mathrm{HW}$ at $30 \mathrm{DAS}$, atrazine $1.0 \mathrm{~kg}$ $\mathrm{ha}^{-1}+\mathrm{HW}$ at $30 \mathrm{DAS}$, combined application of atrazine $0.75 \mathrm{~kg} / \mathrm{ha}+$ pendimethalin 0.75 $\mathrm{kg} \mathrm{ha}^{-1}$ and atrazine $0.75 \mathrm{~kg} \mathrm{ha}^{-1}+$ alachlor $2.25 \mathrm{~kg} \mathrm{ha}^{-1}$ but lowest WCE found with PE application of atrazine $1.0 \mathrm{~kg} \mathrm{ha}{ }^{-1}$, pendimethalin $1.0 \mathrm{~kg} \mathrm{ha}^{-1}$ and alachlor $2.5 \mathrm{~kg}$ $\mathrm{ha}^{-1}$ alone. These results are in agreement with findings of Walia et al., (2007).

Babiker et al., (2013) reported that maximum WCE was observed under treatment of Stomp in combination with Geaprim @(1.5 L a.i $+1.6 \mathrm{~kg}$ a.i) $97.9 \%$ in the first season and $96.6 \%$ in the second season. This finding was in conformity with the result of Patel et al., (2006) who stated that the WCE of $>98 \%$ was achieved with PE application of atrazine in combination with pendimethalin.

With regard to WCE, it was higher (84.41, 92.15 and $89.65 \%$ at 20, 40 and 60 DAS, respectively) in $\mathrm{PE}$ alachlor $1.0 \mathrm{~kg} \mathrm{ha}^{-1}+$ brown manuring. This was closely $f b$ PE alachlor $1.0 \mathrm{~kg} \mathrm{ha}^{-1}+$ daincha as intercrop with in-situ incorporation on 35 DAS (86.04\%) (Ramachandran et al., 2012).

Hawaldar and Agasimani (2012) also reported that the highest WCE at all the stages of crop growth was recorded with sequential application of atrazine $0.75 \mathrm{~kg} \mathrm{ha}^{-1} \mathrm{fb}$ 2,4-D (1.0 kg ha ${ }^{-1}$ ).

Sunitha and Kalyani (2012) reported that PE application of atrazine 0.5 to $1.0 \mathrm{~kg} \mathrm{ha}^{-1}$ in combination with $\mathrm{HW}$ at 30 DAS recorded highest WCE. Sunitha et al., (2010) also observed the highest WCE with PE application of atrazine $1 \mathrm{~kg} \mathrm{ha}^{-1} \mathrm{fb} \mathrm{HW}$ at 30 DAS,

Kumar et al., (2012) concluded that sequential application of atrazine @ (1.5 fb $0.75 \mathrm{~kg} \mathrm{a.i} \mathrm{ha}{ }^{-1}$ ) recorded highest WCE $80.3 \%$ which was closely $f b$ pendimethalin @ $1.5 \mathrm{~kg}$ a.i ha ${ }^{-1}$ as PE $f b$ atrazine @ $0.75 \mathrm{~kg} \mathrm{a.i} \mathrm{ha}^{-1}$ as PoE.

Malviya et al., (2012) reported higher WCE with HW at 20 and 40 DAS $f b$ application of pendimethalin @1.0 kg a.i ha ${ }^{-1}$ as PE and HW at 30 DAS.

Srividya et al., (2011) reported that higher WCE with lower weed index $(21.3 \%)$ was noticed with application of atrazine $1.25 \mathrm{~kg}$ $\mathrm{ha}^{-1}+$ paraquat $0.6 \mathrm{~kg} \mathrm{ha}^{-1}$ application $\mathrm{fb}$ pendimethalin $1.5 \mathrm{~kg} \mathrm{ha}^{-1}+$ paraquat $0.6 \mathrm{~kg}$ $\mathrm{ha}^{-1}$ and these were at par with that of weed free check and IC with power weeder.

\section{References}

Abdullahi, S., Ghosh, G. and Dawson, J. (2016). Effect of different weed control methods on growth and yield of maize (Zea Mays L.) under rainfed condition in Allahabad. Journal of Agriculture and Veterinary Science., 9 (4): 44-47.

Ahmed, M.A.A. and Susheela, R. (2012). Weed management studies in Kharif maize. Research notes. Journal Res. ANGARAU., 40 (3): 121-123.

Anonymous, (2010). National Symposium on Integrated Weed Management in the Era of Climate Change, held at NASC, New Delhi, 21-22 August, 2010.

Arvadiya, L.K., Raj, V.C., Patel, T.U., Arvadiya, M.K. And Patel, A.M. (2012). Influence of plant population and weed management on weed flora and productivity of sweet corn (Zea mays L.). Indian Journal of Weed Science., 44 (3): 167-171.

Babiker, M.M., Salah, A.E. and Mukhtar. M.U. (2013). Impact of herbicides pendimethalin, gesaprim and their combination on weed control under Maize (Zea mays L.). Journal of 
Applied and Industrial Sciences., 1 (5): 17-22.

Barad, B., Mathukia, R. K., Gohil, B. S. and Chhodavadia, S.K., (2016).Integrated weed management in rabi popcorn (Zea mays var. everta). Journal of Crop and Weed., 12 (1): 150-153.

Barla, S., Upasani, R.R, Puran, A.N. and Thakur, R. (2016).Weed management in maize. Indian Journal of Weed Science., 48 (1): 67-69.

Chandran, R.S., Yohn, C.W and Coburn, C.W. (2011). Effect of herbicide banding on yield and biodiversity levels of field corn. Proceedings of Northeast Weed Science Society. 65: 93.

Chhetri, B., Ahmed, S., Mahata, D. and Mahato, S.K. (2014). Bioassay techniques for determination of the dose of atrazine and pendimethalin as pre and post-emergence for Maize (Zea mays) in Terai region of West Bengal. IOSR Journal of Agriculture and Veterinary Science. Volume., 7,: 05-09.

Chopra, P., and Angiras, N. N., (2008). Influence of tillage and weed control methods on weeds, yield and yield attributes of Maize (Zea mays L.).Indian J. Weed Sci., 40 (1\&2): 47 50.

Deshmukh, J.P., Shingrup, P.V., Dandge, M.S., Bhale, V.M. and Paslawar, A.N. (2014). Integrated weed management in maize. Biennial Conference of Indian Society of Weed Science on "Emerging Challenges in Weed Management". Directorate of Weed Science Research, Jabalpur, Madhya Pradesh, India, pp-33 (81).

Deshmukh, L.S., Jadhav, A.S., Jathure, R.S and Rasker, S.K. (2009). Effect of nutrient and weed management on weed growth and productivity of kharif maize under rainfed condition. Karnataka Journal of Agriculture Science., 22 (4): 889-891.
Dimitrios, B., Panayiota, P., Aristidis, K., Sotiria, P., Anestis, K. and Aspasia, E. (2010). Weed suppressive effects of maize-legume intercropping in organic farming. Int. J. pest management: 56 : 173-81.

Ehsas, J., Desai L.J., Ahir, N.B and Joshi, J.R. (2016). Effect of integrated weed management on growth, yield, and yield attributes and weed parameters on summer maize (Zea mays L.) under South Gujarat condition. International Journal of Science, Environment and Technology., 5 (4), 2050-2056.

Gopinath, K.A. and Kundu, S. (2008). Effect of dose and time of atrazine application on weeds in maize (Zea mays L.) under mid-hill conditions of North Western Himalayas. Indian Journal of Agriculture Science., 48 (3): 254-257.

Haji, I.D., Hunshal, C.S., Malligwad, L.H., Basavaraj, B. and Chimmad, V.P. (2012). Effect of pre and post emergence herbicides on weed control in maize (Zea mays L.). Karnataka J. Agric. Sci., 25 (3): 392-394.

Hatti, V., Sanjay, M.T., Prasad, T.V.R., Murthy, K.N.K., Kumbar, B. and Shruthi, M. K. (2014). Effect of new herbicide molecules on yield, soil microbial biomass and their phytotoxicity on maize (Zea mays L.) under irrigated conditions. The Bioscan., 9 (3): 1127-1130.

Hawaldar, S. and Agasimani, C.A. (2012). Effect of herbicides on weed control and productivity of maize (Zea mays L.). Karnataka J. Agric. Sci., 25(1): 137- 139.

Jagadish, Shrinivas, C. S., Prashant. (2016). A review on weed management on maize (Zea mays L.). Advances in Life Sciences., 5 (9): 3448:3455.

Jat, R.K., Gopar, R. and Gupta, R. (2012). Conservation agricultural in maizewheat cropping systems of eastern 
India: Weed dynamics and system productivity. In: Extended summaries Vol. 3, 3rd International Agronomy Congress, November 26-30, 2012, New Delhi, India.

Kakade, S.U., Deshmukh, J.P., Bhale, V.M., Solanke, M.S. and Shingrup, P.V. (2016). Efficacy of pre and post emergence herbicides in Maize. Extended Summaries Vol. 1: 4th International Agronomy Congress, Nov. 22-26, 2016, New Delhi, India. pp 442-443.

Kannan, S. and Chinnagounder, C. (2013). Evaluation of bio-efficacy, weed control efficiency in herbicide resistant transgenic stacked and conventional corn hybrids (NK603 x TC 1507) for crop productivity. International Journal of Scientific and Research Publications., 3 (7).

Kannan, S. and Chinnagounder, C. (2014). Effect of glyphosate on weed management and grain yield in Kharif maize of transgenic stacked and conventional maize hybrids for higher productivity. Academic Journals., 9 (2), 269-275.

Kumar, A., Kumar, J., Puniya, R., Mahajan, A., Sharma, N. and Stanzen, L. (2015).Weed management in maizebased cropping system. Indian Journal of Weed Science., 47 (3): 254-266.

Kumar, B., Kumar, R., Kalyani, S., and Haque, M. (2013). Integrated weed management studies on weed flora and yield in kharif maize. Trends in Biosciences., 6 (2): 161- 164.

Kumar, B., Prasad, S., Mandal, D. and Kumar, R. (2017). Influence of integrated weed management practices on weed dynamics, productivity and nutrient uptake of rabi maize (Zea mays L.). International Journal of Current Microbiology and Applied Sciences., 6 (4): 1431-1440.
Kumar, R., Saini, J.P., Chadha, S and Kumar, R. (2015). Weed suppression in maize with legume intercrops and sowing pattern under organic conditions in NW Himalayas. Green Farming., 6 (1): 161163.

Kumar, S., Rana, S.S., Chander, $\mathrm{N}$ and Angiras, N. (2012). Management of hardy weeds in maize under mid-hill conditions of Himachal Pradesh. Indian Journal of Weed Science., 44 (1): 11-17.

Kumari, G. A., Sanjay, M.T., Ramachandra Prasad, T.V., Devendra, R.D., Rekna, M.B and Munirathamma, C.M. (2014). Yield and yield attributes of maize as influenced by different management practices. Biennial conference on "Emerging challenge in weed management" Organized by Indian Society of Weed Science.15- 17, February.

Madhavi, M., Ramprakash, T., Srinivas, A and Yakadri, M. (2014). Topramezone (33.6\% SC) + Atrazine (50\%) WP tank mix efficacy on maize. Biennial conference on "Emerging challenge in weed management" Organized by Indian Society of Weed Science.15-17, February.

Madhavi, M., Ramprakash, T., Srinivas, A., Yakadri, M. (2013). Integrated weed management in maize (Zea mays L.) for supporting food security in Andhra Pradesh, India. The role of weed science in supporting food security by 2020. Proceedings of the 24th Asian-Pacific Weed Science Society Conference, Bandung, Indonesia, October 22-25, 2013.

Malviya, A., Malviya, N., Singh and Band Singh, A.K. (2012). Integrated weed management in maize (Zea mays L.) under rainfed conditions. Indian Journal of Dryland Agriculture Research \& Development., 27(1): 7073. 
Mathukia, R.K., Dobariya, V.K., Gohil, B.S. and Chhodavadia, S.K. (2014). Integrated weed management in rabi sweet corn (Zea mays L. var. Saccharata). Advances in Crop Science and Technology. 2: 4.

Mukherje, P.K. and Rai, A. (2015). Weed management in no-tilled dibbling maize within rice residue. 25th Asian-Pacific Weed Science Society Conference on "Weed Science for Sustainable Agriculture, Environment and Biodiversity", Hyderabad, India during 13-16 October, 2015. pg. 148.

Nadeem, M.A., Awai, S. M., Ayub, M., Tahir, M and Maqbool, M. (2010). Integrated weed management studies for autumn planted maize. Pakistan Journal of Life Science Society., 8 (2): 98-101.

Nadiger, S., Babu, R., and Aravinda Kumar, B.N. (2013). Bioefficacy of pre emergence herbicides on weed management in maize. Karnataka Journal of Agricultural Science., 26 (1): 17-19.

Patel, V.J., Upadhyay, P.N., Patel, J.B. and Patel, B.D. (2006). Evaluation of herbicide mixtures for weed control in maize (Zea mays L.) under middle Gujarat conditions. The Journal of Agricultural Sciences., 2 (1).

Pathak, P.K., Singh, S., Rinwa, R. S. and Singh, S. (2015). Efficacy of different weed control methods inspring planted maize. Haryana J. Agron., 31 (1\&2): 92-97.

Prasad, A., Singh, G. and Upadhyay, R.K. (2008). Integrated weed management in Maize (Zea mays L.) and Maize + Blackgram. Indian journal of Weed Science., 40 (3\&4): 191-192.

Ramachandran, A., Veeraman, I.A. and Prema, P. (2012). Effect of brown manuring on weed growth, yield and economics of irrigated maize. Indian
Journal of Weed Science., 44 (3): 204 206.

Ramesh, G. and Nadanassababady, T. (2005). Impact of herbicides on weeds and soil ecosystem of rainfed maize (Zea mays). Indian Journal of Agricultural Research., 39 (1): 31-36.

Rani, B.S., Sagar, G.K. and Reddy, P.M. (2011). Effect of integrated weed management with low volume herbicides in sweet corn (Zea mays). Indian Journal of Weed Science., 43 (1\&2): 110-112.

Rasool, S. and Khan, M.H. (2016).Growth and yield of maize (Zea mays L.) as influenced by integrated weed management under temperate conditions of North Western Himalayas. American Journal of Experimental Agriculture., 14 (1): 1-9.

Ravisankar, D., Chinnusamy, C. and Muthukrishnan, P. (2013). Influence of post emergence application of glyphosate on weed control efficiency and yield of transgenic maize. American Journal of Plant Sciences., 4: 15621567.

Reddy, M.M., Padmaja. B., Veeranna, G. and Reddy, D.V.V. (2012). Bio-efficacy and economics of herbicide mixtures in zerotill maize (Zea mays) grown after rice (Oryza sativa). Indian Journal of Agronomy 57(3): 255-258.

Rout, D. and Satapathy. (1996).Chemical weed control in rainfed maize (Zea mays). Indian Journal of Agronomy., 41: 51-53.

Sahoo, T.R., Hulihalli, U.K., Paikaray, R.K., Mohapatra, U. and Sethi, D. (2017). Saflufenacil: A new group of chemical herbicide for effective weed management in maize. International Journal of Chemical Studies., 5 (1): 339-342.

Saini, J.P., Punam, R., Chadha, S., Sharma, S., Bhardwaj, N. and Rana, N. 
(2013).Non-chemical methods of weed management in maize under organic production system. Indian Journal of Weed Science., 45(3): 198-200.

Samanth, T. K., Dhir, B.C., Mohanty, B. (2015). Weed growth, yield components, productivity, economics and nutrient uptake of maize (Zea mays L.) as influenced by various herbicide applications under rainfed condition. Indian Journal of Weed Science., 2 (1): 79-83.

Sanodiya, P., Jha, A.K. and Shrivastava, A. (2013). Effect of integrated weed management on seed yield of fodder maize. Indian Journal of Weed Science., 45 (3): 214-216.

Sarma, C.K. and Gautam, R.C. (2010). Weed growth, yield and nutrient uptake in maize (Zea mays) as influenced by tillage, seed rate and weed control method. Indian Journal of Agronomy., 55 (4): 299-303.

Shankar, K.A., Yogeesh, L.N, Prashanth, S.M., Channabasavanna, A.S. and Channagoudar, R.F. (2015). Effect of weed management practices on weed growth and yield of maize. International Journal of Science, Environment and Technology., 4 (6): 1540-1545.

Sharma, A. R., Toor, A. S. and Sur, H. S. (2000). Effect of interculture operations and scheduling of atrazine application on weed control and productivity of rainfed maize (Zea mays) in Shiwalik foothills of Punjab. Ind. J. agric. Sci., 70: 757-761.

Shingrup, P.V., Dandge, M.S., Paslawar, A.N., Bhale, V.M. and Deshmukh, J.P. (2014). Efficacy of pre emergence herbicides on maize-chickpea cropping sequence. Biennial Conference of Indian Society of Weed Science on "Emerging Challenges in Weed Management". Directorate of Weed
Science Research, Jabalpur, Madhya Pradesh, India, pp-35(88).

Singh, A. and Dangwal, L. R. (2013). A survey of weed flora in maize fields of district Rajouri (J\&K), India. International Journal of Scientific Research., 2(1): 6-9.

Singh, A.K., Parihar, C.M., Jat, S.L., Singh, B. and Sharma, S. (2015).Weed management strategies in maize ( $\mathrm{Zea}$ mays): Effect on weed dynamics, productivity and economics of the maize- wheat (Triticum aestivum) cropping system in Indo-Gangetic plains. Indian Journal of Agricultural Sciences. 85 (1): 87-92.

Singh, R., R.P. Dubey, R.P., Singh, V.P., Ghosh, D., Srarthmbal, C., Barman, K.K. and Choudhury, P.P. (2015). Impact of tillage, residue and weed management on growth and yield of maize.25th Asian-Pacific Weed Science Society Conference on "Weed Science for Sustainable Agriculture, Environment and Biodiversity", Hyderabad, India during 13-16 October, 2015.pg 151.

Singh, V.P., Guru, S.K., Kumar, A., Banga, A. and T, N. (2012). Bioefficacy of tembotrione against mixed weed complex in maize. Indian Journal of Weed science 44 (1): 1-5.

Sraw, P.K., Kaur, A. and Singh, K. (2016). Integrated weed management in kharif maize at farmers field in Central Punjab. International Journal of Agricultural Science and Research., 6 (2): 97-100.

Srividya, S., Chandrasekhar, K. and Veeraraghavaiah. (2011). Effect of tillage and herbicide use on weed management in maize (Zea mays. L). Andhra Agric. J., 58 (2): 123-125.

Stanzen, L., Kumar, A., Sharma, B.C., Puniya, R. and Sharma, A. (2016). Weed dynamics and productivity under 
different tillage and weed-management practices in maize (Zea mays)- wheat (Triticum aestivum) cropping sequence. Indian Journal of Agronomy., 61 (44): 449-454.

Sultana, S., A, Md., Ahmed, N. and Karim, Md., F. (2012). Effect of weed management practices on weed biomass and grain yield of hybrid maize in Northern Bangladesh. World Journal of Agriculture Sciences., 8 (1): 62-65.

Sunitha, N. and Kalyani, D.L. (2012).Weed management in maize (Zea mays L.) - A review. Agri. Reviews., 33 (1): 70 -77.

Sunitha, N., Reddy, P.M. and Sadhineni, M. (2010). Effect of cultural manipulation and weed management practices on weed dynamics and performance of sweet corn (Zea mays L.). Indian $J$. Weed Sci., 42 (3\&4): 184-18.
Swetha, K. (2015).Weed management with new generation herbicides in kharif maize (Zea mays L.). M.S. (Ag.) Thesis. Professor Jayashankar Telangana State Agricultural University, Hyderabad, India.

Verma, V.K., Tewar, A.N and Dhemri, S. (2009). Effect of atrazine on weed management in winter maize-green gram cropping system in central plain zone of Uttar Pradesh. Indian Journal of Weed Science., 41 (1\&2): 41-45.

Walia, U.S., Singh, S. and Singh, B. (2007). Integrated control of hardy weeds in maize (Zea mays L.). Indian Journal of Weed Science., 39 (1\&2):17-20.

Yakadri, M., Rani, P.L., Prakash, T.R., Madhavi, M. and Mahesh, M. (2015).Weed management in zero tillmaize. Indian Journal of Weed Science., 47(3): 240-245.

\section{How to cite this article:}

Anwesh Rai, Debasis Mahata, Everest Lepcha, Kousik Nandi and Pijush Kanti Mukherjee. 2018. A Review on Management of Weeds in Maize (Zea mays L.). Int.J.Curr.Microbiol.App.Sci. 7(08): 2906-2922. doi: https://doi.org/10.20546/ijcmas.2018.708.308 